\title{
Sexual differences in the consumption of food by Homo sapiens: some speculations in archeogastronomy and the evolution of eating patterns
}

\author{
Graham Pont \\ Balmain, NSW, Australia. Private Scholar; graham_pont@hotmail.com
}

Received 5-IV-2012 Corrected 26-VI-2012 Accepted 16-VII-2012

\begin{abstract}
In traditional societies, men are more likely to consume substantial amounts of food in a few daily meals, whereas women tend to consume smaller quantities of food but to do it more frequently during the day. Here I propose the hypothesis that this behavior has a biological basis because in hunting-gathering societies, it was the men who did the hunting over large areas and had to wait until a kill was made to eat (often a large amount of food in a single sitting), while women moved in a more restricted area, did the gathering and frequently ate some of the small pieces of food that they found. I suggest that in gastronomic and spatial terms, the orientation of the male is extra-territorial and the orientation of the female is predominantly intra-territorial.
\end{abstract}

\section{KEY WORDS}

Evolution of human behavior, sexual differences in feeding patterns and spatial skills, possible implications for art, philosophical inquiry.

\section{RESUMEN}

En las sociedades tradicionales, los hombres son más propensos a consumir grandes cantidades de alimentos en unas pocas comidas diarias, mientras que las mujeres tienden a consumir pequeñas cantidades de comida, pero con más frecuencia durante el día. Aquí propongo la hipótesis de que este comportamiento tiene una base biológica, porque en las sociedades de cazadores-recolectores, los hombres hacían la caza en grandes áreas y comían abundantemente al obtener una presa, mientras que las mujeres se movían en una zona más restringida, recolectaban y con frecuencia comían de los pequeños alimentos hallados. Sugiero que en el sentido gastronómico, la orientación del hombre es extra-territorial y la orientación de la mujer es predominantemente intra-territorial.

\section{PALABRAS CLAVE}

Evolución del comportamiento humano, diferencias sexuales en los patrones de alimentación, posibles consecuencias sobre el arte, investigación filosófica.
At the Fifth Symposium of Australian Gastronomy (Adelaide, March 10-13, 1990) there was a panel session devoted to 'The Pleasures of the Table' which took its title and theme from Meditation XIV of Jean-Anthelme BrillatSavarin's Physiologie du goût, ou méditations de gastronomie transcendante... par un professeur (1825, Paris). This immortal work also inspired the following meditations on the pleasures of the prehistoric table. In the spirit of the Professor's own imaginative essays in speculative gastronomy, I have tried to explain two seemingly unrelated differences between men and women in terms of prehistoric eating habits.

The first of these differences is the evident fact that men are more likely to reserve their eating for a substantial meal - often, but not necessarily a dinner at the end of the working day - whereas women tend to refresh themselves with smaller quantities of food taken more frequently. General speaking, it is men who feast and women who snack (Flor-Henry, 1978; Harris, 1978; Wyborg, 1983). History shows that feasts, banquets, drinking bouts, etc. have been predominantly male institutions, from which women were often excluded altogether. The modern dinner party, with its careful balance of the sexes and more or less equal sharing of the food and drink, is a polite innovation which goes back no more than a few hundred years. But even in the most enlightened and egalitarian societies, it has usually been considered proper for women to eat and drink less on these occasions - or at least appear 
to be doing so. There may be sound biological reasons for this custom: some medical researchers are now arguing that men have a different alcohol metabolism from women, whose blood alcohol levels are comparably raised by half as many drinks.

The second sex difference is one well known to psychologists: experiments have repeatedly shown that men and women differ in their sense of space and that, generally speaking, men are more competent in spatial tasks. A fortiori, this difference of spatial perception extends to the sense of direction. As a non-driver who has enjoyed the pleasure of being driven around for many years by competent and intelligent women, I have observed that their sense of direction often varies markedly with the area being traversed. Close to their own home, town or suburb - their normal living or working environment - women are more confident as drivers; but, as soon as they leave their familiar territory, they frequently become less confident, more apprehensive and sometimes get lost. This sudden change of spatial competence or loss of orientation does not appear to be dependent on levels of intelligence or driving experience. The critical factor seems to be territorial: women's spatial sense is somehow bound up with proximity to their living/working area - the camp, the cave, the castle, the cottage, the condominium and so on.

These striking sex-differences, of eating habits and spatial skills, might both be explained by a common cause in prehistory. For untold millennia, human beings lived in a hunter-gatherer economy like that which can still be observed in a few tribal societies not yet dependent on agriculture. Traditionally, it was the men who did the hunting and the women and children who did the gathering. The hunting, a more precarious and less reliable source of food, often involved the men in distant and strenuous journeys away from the camp, unpredictable meal-times, and the duty of bringing home at least some of the catch at the end of the hunt. The game was free-range and highly nutritious but sometimes not really worth all the spectacular effort. Catching it often led the men into remote or unfamiliar territory from which they had to find, perhaps fight, their way home. For a hundred, perhaps two hundred thousand years - for as long as our particular species has been around - the male life-style depended critically on having a good sense of direction, as well as related skills in estimating the size, shape, numbers and whereabouts of the game and competing predators. In the struggle for survival, spatially and numerically incompetent males would be obvious losers. So archeogastronomy might also explain why most mathematicians are males. Some authors have reported a defined sex ratio of mathematical skill (Moir \& Jessel, 1991).
Meanwhile, back at the camp, the women looked after the children, devoting much of their free time and energy to collecting edibles nearby - not just fruits, nuts, roots and grains for bread, but also grubs, insects, seafood and sometimes smaller game too. Unlike the men, the women were able to gather these staple foods without needing exceptional spatial skills or long-range direction-finding. They habitually kept in close touch with the camp, with the children and with each other - habits which might help to explain the distinctive character of female sociability as well as the rarity of female hermits and mystics communing alone with nature. The solitary hours of the hunter and the fisherman were always conducive to thought and contemplation; fasting was an unavoidable part of the business and the rarer catches a justifiable reason for the long-awaited feast or celebration. As Bo Lawergren has insightfully suggested, the first speculative musician was probably a bored hunter, leaning on his bow, hungrily chewing the end and accidentally plucking the string (Lawergren, 1988).

For women, however, the quiet and regular gathering of the less prestigious but more accessible foods encouraged other virtues and values - easy social contact, intermittent gossip, the gentle art of gardening (traditionally, a female invention) and the impromptu sharing of tidbits with each other and with the children (who also prefer to snack). Furthermore, women are often better collectors of small organisms in the field of Natural History (Zaidett Barrientos, unpublished). In the more old-fashioned, unequal societies, such as parts of Italy and the Near East, the women still stand and serve the food while the men sit and eat. Here, surely, we find an ancient prototype of the full-time housewife and mother, welcoming home her tired husband for whom the dinner of the end (or, formerly, in the middle) of the working day is much more a necessary restorative than just a sharing of social and domestic pleasures.

The gathering and preparation of food by the women usually occurs in a closed or more closely defined territory. The more intimate scale of the feminine landscape might ultimately explain why all the famous architects are men, whereas women (and effeminate men) dominate the arts of interior design, soft furnishing and small-scale decoration. Landscape art is an interesting grey area, more often entered by women from the enclave of the garden, and by men from the larger domains of architecture, engineering, surveying and town-planning. Thus one might go on to distinguish between characteristically male and female styles of landscape: the landscape paintings of women are generally much more domestic or home-centred than those of their male counterparts, whose locus and focus lie further afield. The wider, wilder landscape has always 
been the male preserve: hence, in music, painting and the constructive arts, the Sublime seems to be almost an exclusively male genre. In Women Painters of the World (Shaw, 1905) there are many landscapes illustrated but only two or three bordering on the Sublime. 'It is at first sight a curious thing that more women painters have not been attracted by pure landscape' (Shaw, 1905, p. 69). In The Obstacle Race (Greer, 1979), the Sublime is not indexed and no sublime landscapes appear among the 358 works illustrated. The only borderline cases, perhaps, are two or three battle scenes. It remains to be seen if this pattern can be explained by other factors, for example a tendency of artists to paint what they are acquainted with, together with the restrictions that society has long kept on women's movements outside the home.

Gender-specialization and instinctual foodways might even explain one of the most fundamental sex differences of all: the mobile, wide-ranging hunters could hardly avoid being exploratory, invasive, inquisitive, spontaneous, aggressive and bellicose in competing with other tribes and animals for food; but the women at home could bring in their sure and steady contributions to the larder without deadly strife. They had their own internal squabbles, of course; but they were mostly conducted within the boundaries defined and defended by the men. Prehistory probably saw many other Helens who caused unrecorded inter-tribal wars, but, on the other hand, the recent Duntley-Buss Biological Model of Murder is based on the greater number of human lives taken by women, a fact often ignored (Duntley and Buss, 2011).

In spatial as well as gastronomic terms, the orientation of the male is extra-territorial: he goes out to hunt, to fight, to kill - or to review restaurants. The orientation of the female is predominantly intra-territorial: she stays within and gathers around the camp - caring, nurturing, holding, storing, waiting. In religions, recipes and restaurants, it is more often men who venture, discover and forget - and women who protect, conserve and remember. It is easy to see why Brillat-Savarin's Tenth Muse, the well-endowed Gastéréa, should be female: but the femininity of her sister Muses and Mnemosyne, the Mother of all memory, has similarly deep roots in the evolutionary specialisation of the sexes. See BrainSex (Mori \& Jessel, 1991, p. 19). Few females have achieved fame as inventors or explorers: more often they are identified with the invented and explored. For example, the temple of Gastéréa, in the Physiology of Taste, is a Baconian Solomon's House devoted to the investigation and transformation of Mother Nature. Again, this may also simply reflect limitations imposed by society on women.

Is it possible, then, that human spatial abilities and gastronomic inclinations could both have been biologically determined and sexually differentiated by the archaic organization of the hunter-gather economy? If so, we can roughly date the emergence of that specialisation from the time when our remote tree-dwelling ancestors abandoned their common arboreal space and vegetarian life-style to become upright, bipedal and omnivorous predators in the open countryside. If it is true that 'the fundamental morphological organization is female' and that 'the male gender in primates is a specialization of the basic female paradigm' (Henry, 1978) there remains the interesting question of when and how the hunter's spatial skill was acquired in the course of evolution. Long-range distance-finding would hardly have been a useful skill for our arboreal ancestors. Nevertheless, considering that the institution of agriculture and the urban civilisation it made possible occupy only a few minutes in the vast year of human evolution, it is not all unlikely that the lifestyle and traditional foodways of our pre-urban ancestors have left their deep imprint on the predilections and propensities of modern human beings. Hearing tests reveal that boys are better than girls at identifying animal noises - possibly the evolutionary result of those millennia of hunting (Moir \& Jessel, 1991, p. 62.)

In his fourth Aphorism Brillat-Savarin rightly declared: 'Tell me what you eat and I will tell you what you are'.

But are we, then, sexist - and spatialist - by nature as well as nurture?

Shortly after the Symposium, my colleague and copanelist Dr. Barbara Santich sent me this quotation:

'It is unlikely that there has been major biological changes in man since the Neolithic revolution... the selection pressures associated with hunter-gathering have been predominant in determining man's genetic constitution'. (Powles 1973)

\section{REFERENCES}

Duntley, J.D. \& D. M. Buss. (2011). Homicide adaptations. Aggression and Violent Behavior, 16: 399-410.

Flor-Henry, P. (1978). Gender, Hemispheric Specialization and Psychopathology. Social Science and Medicine, 128: 155-162

Greer, G. (1979). The Obstacle Race: The Fortunes of Women Painters and Their Work. London, England: Martin Secker and Warburg.

Harris, L.J. (1978). Sex differences in spatial ability: possible environmental, genetic, and neurological factors. In M. Kinsbourne (ed,) Asymetrical Function of the Brain. Chapter 13. Cambridge, UK: Cambridge University Press. 
Lawergren, B. (1988). The Origin of Musical Instruments and Sounds. Anthropos 83: 31-45

Moir, A. \& Jessel, D. (1991). Brain Sex: The Real Difference Between Men and Women. London, England: Mandarin.

Nyborg, H. (1983). Spatial Ability in Men and Women: Review and New Theory. Advances in Behaviour Research and Therapy, 5: 89-140.
Powles, J. (1973). On the Limitations of Modern Medicine. Science, Medicine and Man 1:4

Sparrow. W.S. (1905). Women Painters of the World: From the Time of Caterina Vigri, 1413-1463, to Rosa Bonheur and the Present Day. Cambridge, Massachusetts: Hard Press. 